\title{
INFLUENCE OF RESTORATIVE JUSTICE ON PRISON SYSTEM ${ }^{\star}$
}

\author{
Tomáš Strémy, Ph.D.** \\ Comenius University in Bratislava, Faculty of Law \\ Jozef Griger \\ General Directorate of the Corps of Prison \\ and Court Guard (Slovak Republic)
}

* This publication has been produced with the support of The Slovak Research and Development Agency and is the result of project No. APVV-17-0217 "Service actions performed by a police officers and the application of a principle of appropriateness from the perspective of criminal and administrative law".

** tomas.stremy@flaw.uniba.sk 



\title{
INFLUENCE OF RESTORATIVE JUSTICE ON PRISON SYSTEM
}

\begin{abstract}
History of imprisonment has been conceived and organised in a variety of ways. Reformers tried to shape the prison regime to suit their purposes, but the reality of the prison system displayed the substantial limits of their achievements (for example high costs for construction of prisons; level of criminality, minimum protection of future victims etc.). In the second half of the 20th century, a search for new ways of solutions of criminality and penal policy begins. The idea of a restorative prison exists at the moment in concept only. This concept is based on the opportunities for prisoners to encounter their actual victims for restorative dialogue. Restorative programs also enhancing the return of prisoners into family environment and community and improve a dynamic security in prison.
\end{abstract}

Key words: prison, prison sentence execution, restorative justice, restorative programs

\section{Introduction}

Prison system is an integral part of the penal law system - a man behind bars is one of the most serious issues of penal politics. Despite the fact that the evolution of the conservative imprisonment system reacted to the revolutionary ideas of the enlightenment period, development of human rights and freedoms and building of the democracy with a slight time gap that was dependent on the current state of the society, the prison system has remained a symbol of the retributive justice. Although the concept of the restorative solution of the consequences of a criminal act seems to be different from the institutes of pre-trial detention and prison sentence execution or historically it arises just in order to circumscribe against the classical retributive system, principles, ideas and techniques of the restorative justice find their place gradually also in fulfilling the purpose of impri- 
sonment. The aim of the submitted contribution is to doubt the exclusively retributive perception of the prison system, to identify the restorative principles in treatment of inmates in the current Slovak legislation and to find out the influence of the standardized restorative programmes on settlement of relations between the offender and the victim, enhancement of the return of the prisoner to the family environment and ensuring dynamic security inside prisons. We also touch upon the past, but only if it has a meaning for understanding the presence, (knowledge rises from knowing the past).

\section{Prisons and Prison System}

Currently, the prison system can be characterized as a complex of institutions and purposefully arranged activities in execution of penal policy of the state focused on protection of social relations by

- Temporary restriction of the freedom of movement of persons suspected of a crime for purposes of prosecution (pre-trial detention) and persons legally sentenced for criminal offences (prison sentence execution) and

- Creating conditions for rehabilitation of persons in prison sentence execution, change of their attitudes to crime and integration into society.

The current form of custody is a result of a long development in the understanding of the purpose of the prison sentence. In the antiquity, there have been practically no prisons and prison systems, as its fundamental attribute - restriction of the freedom of movement - was a natural part of the slave social establishment (a slave was permanently restricted in the freedom of movement). ${ }^{1}$ Prisons existed only as places for ensuring the presence of a slave or citizen in case of official procedures or as places of assembly and isolation of socially and politically redundant people. This state continued until the end of feudalism. At the start of renaissance and humanism and after removal of the feudal legal fragmentation, there was a substantial shift in the penal policy. Apart from formation of several safe-

1 The criminal penalty differed according to the class and corporative belonging, because there was different law. There was no fixed system of either facts of the case of crimes or punishments - there was a significant arbitrariness where mainly vengeance, revenge and slanders connected with loss of property for the benefit of the establishment in case of full citizens prevailed. 
guards guaranteeing a just punishment of offenders of crimes ${ }^{2}$, the theory of sentences passes from the absolute revenge to the theory of "just revenge" (retribution) and definite severity of sentences. In this sense, prisons had a function of a revenge by evil for evil. The sentence was strictly defined by decision of a court based only on severity of the crime and was not subject of any further changes apart from extraordinary cases of pardon or amnesty. Similarly as duration, also the sentence regime was defined as a stereotype. Jail was a place where the prisoner should have pay for his blame in difficult life conditions (Paníček, 1970: 192). The prison environment and overall organisation of the prison system were adequate to this purpose (the first prison systems rise based on a strict isolation of inmates).

Pure repression gradually started to lose its force. It was shown, that the strictness of prisons is not enough for crime reduction. Vice versa, the strict regime in its execution usually created either even more horrendous criminals or persons without any ability of social integration. Thus, another principle started to join the revenge - the principle of re-education. The new idea started to be reinforced in the second half of the $19^{\text {th }}$ century and developed fully only in the $20^{\text {th }}$ century. In the corrective prison system, the revenge is not the aim of the punishment, but one of several means of re-education. Emphasis is put on the influence of the character of the prisoner and efforts to create such a regime in prison environment that would prepare inmates for their return into life at large. The idea to make the punishment more humane and at the same time more effective becomes a devise of the reform efforts (Fábry, 2012: 26). Prison system is not merely a mirror of penal policy but the knowledge of its effects retroactively influences the penal policy.

All modern penal systems understand prisons multi-dimensionally they aim not at liquidation of the offender, but at his rehabilitation that has to rely on the internal persuasion of the offender of fairness, i.e. proportionality of the penalty. Thus, the individual prevention is based on the sense of blame and proportionality of the penalty. The ambition of the modern prison system is not to isolate from the life, for which the prisoner shall be brought up, but to become as close as possible to the life (Paníček, 1970: 103).

In geographical conditions of the Slovak Republic, the prison system passed the abovementioned periods as a part of the Austro-Hungarian and later the Czechoslovak legal environment. At the end of the $18^{\text {th }}$ century,

2 Nullum delictum sine lege (prosecution guarantee); nulla poena sine lege (penalty guarantee); nulla justicia sine lege (procedure guarantee); nulla poena sine crimen (sanction guarantee). 
the classical system of prisons arises on our territory when along the penal codes of Joseph II and continuous system of court prisons the first countrywide prison facility determined for prison sentence execution is established in Senec (1770) - in 1780 translocated to Tomášikovo. In 1840, the system of solitary confinement was adopted as the basis of the Hungarian prison system (on our territory, the Komárno jail and Bratislava detention facility were established in this system). Following the legislation of the 1952 Austrian Penal Code, two houses of corrections arose on our territory - in Leopoldov and Ilava. Apart from these houses of corrections, until the end of the $19^{\text {th }}$ century another 10 royal court prisons were established on our territory, namely in Bratislava, Nitra, Trenčín, Komárno, Banská Bystrica, Ružomberok, Rimavská Sobota, Levoča, Košicie and in Prešov (Fábry, 2012: 29). The Austro-Hungarian Compromise in 1867 brought significant changes in the sphere of the prison system. The prison system was subordinated to the Ministry of Justice and profited from the first Hungarian Penal Code that was adopted as the article V. of 1878. The legal prerequisites lead to the introduction of the so-called Irish progressive system including the transitional facility as a level before the conditional release. No more significant changes in the prison system occurred on our territory even between the wars of the $1^{\text {st }}$ Czechoslovak Republic. Only the second half of the 1960 s marked by the dynamic development and reform efforts in all areas of the State, reflects also in the prison system. The adoption of the Act No 59/1965 Coll. on Prison Sentence Execution ${ }^{3}$ meant breakthrough changes:

- Legislation of conditions of prison sentence execution that replaced the previous exclusive regulation of the prison sentence execution by internal by-laws and

- Introduction of the system of a differentiated and progressive prison sentence execution.

It is also necessary to stress the fact that when creating the Act No 59/1965 Coll. ${ }^{5}$ the submitters came out and in many respects accepted the Standard Minimum Rules for the Treatment of Prisoners adopted by the United Nations in Geneva ${ }^{4}$ and later also their modified and modernised form - the European Prison Rules adopted by the Council of Europe ${ }^{5}$.

3 Act No 59/1965 Coll. on Prison Sentence Execution of 17 June 1965 retrieved from https://www.slovlex.sk/pravne-predpisy/SK/ZZ/1965/59/20030901.

4 The UN Standard Minimum Rules for the Treatment of Prisoners of 31 July 1957 retrieved from https:// www.unodc.org/pdf/criminal_justice/UN_Standard_Minimum_Rules_for_the_Treatment_of_Prisoners.pdf

5 Recommendation No. R (87) 3 on the European Prison Rules of 12 February 1987 retrieved from https://rm.coe.int/16804f856c. 
Socio-economic changes that arose in our society after 1989, reflected gradually in all social areas including the prison system. In 2005, the criminal codes were re-codified. The generally binding regulations governing the prison system followed the adoption of the new Penal Code and Code of Criminal Procedure:

- Act No 221/2006 Coll. on Pre-Trial Detention, ${ }^{6}$

- Decree of the Ministry of Justice of the Slovak Republic No 437/2006 Coll. that issues Rules of Pre-Trial Detention, ${ }^{7}$

- Act No 475/2005 Coll. on Prison Sentence Execution as amended ${ }^{8}$ and

- Decree of the Ministry of Justice of the Slovak Republic No 368/2008 Coll. that issues Rules of Prison Sentence Execution. ${ }^{9}$

If the criminal law refuses to build on the principle that the punishment is only a revenge for the committed crime, also the generally binding regulations governing the prison area build on this postulate and apart from the protective function they affect the inmates concerning their social reintegration by all activities. The essential idea is to pass from viewing the person as a passive object of penitentiary care to such an acting where he himself will be an active agent. The inevitable consequence of resocialisation as the final objective of prison sentence execution are the efforts to create a regime in the prison that would prepare for the return to life at large. Namely, it is not possible to prepare an inmate for a normal life in completely different conditions of isolation from society, there are efforts to bring closer the regime of life of inmates in so far as possible to the life at large. Brutal force can create good inmates, but only moral power can create good citizens (Paníček, 1970: 103).

6 Act No 221/2006 Coll. on Pre-Trial Detention of 15 March 2006 retrieved from https://www.slov-lex.sk/ pravne-predpisy/SK/ZZ/2006/221/20160701.

7 Decree of the Ministry of Justice of the Slovak Republic No 437/2006 Coll. that issues Rules of Pre-Trial Detention of 26 June 2006 retrieved from https://www.slov-lex.sk/pravne-predpisy/SK/ ZZ/2006/437/20150701

8 Act No 475/2005 Coll. on Prison Sentence Execution of 22 September 2005 retrieved from https://www. slov-lex.sk/pravne-predpisy/SK/ZZ/2005/475/20190701

9 Decree of the Ministry of Justice of the Slovak Republic No 368/2008 Coll. that issues Rules of Prison Sentence Execution of 3 September 2008 retrieved from https://www.slov-lex.sk/pravne-predpisy/SK/ ZZ/2008/368/20160101 


\section{Restorative justice}

In the second half of the $20^{\text {th }}$ century, a search for new ways of solutions of criminality and penal policy begins. It is based on the knowledge that previous penal policy based on the state monopoly does not represent any adequate reaction to the increase of criminality and leads rather to an impersonal protection of individuals and society, high costs for construction of prisons, whose isolation and resocialisation activities do not decrease the level of criminality and do not protect future victims. The $10^{\text {th }}$ United Nations Congress on the Prevention of Crime and the Treatment of Offenders in Vienna in 2000 emphasized that in many countries, penal justice systems still focus too much on the reaction of public to the committed crime rather than focusing on ensuring justice for victims and offenders. ${ }^{10}$ Views on the need of an alternative insight based on enforcement of the roles of victims and offenders in solution of crimes as a conflict between these persons start gradually to promote - the concept of restorative justice arises. Essentially, the restorative justice paradigm is based on the assumption that crime is a damage to persons and relations rather of a common breach of the laws.

Restorative movement originated spontaneously in many countries of the Anglo-American as well as the Continental legal model. This concept did not arise as a clearly structured model or a compact system of how the active finding of justice should function (Mccold, 2006: 36). It is rather a set of principles, ideas, aims, methods and activities stressing the rights of victims - their protection and searching the possibility of restoration of the original state impaired by a crime. ${ }^{11}$ Therefore, the offender has an important role in this concept along with the victim; however not as the object of the penalty, but as an active subject of restoration of the impaired state. The offender is committed to put "the things in order", accept consciously the responsibility for the caused harm, openly and sincerely discuss his criminal behaviour and has to adopt the mechanisms of management of conflict situations and habits that lead him to crime. Restorative justice approaches mind also removal of consequences of the committed crime that can show also on the level of community to which the victim and offender belong (Barnett, 2004: 46).

10 Report of the Tenth United Nations Congress on the Prevention of Crime and the Treatment of Offenders, 10-17 April 2000, A/CONF.187/15 retrieved from https://digitallibrary.un.org/record/432663? ln=en

11 It is not only return of the material harm that was caused to the victim, but mainly work with the emotional damage caused to the victim and that needs to be compensated - help the victim to cope with it. 
Despite the concept of crime solution as a social conflict between the offender, victim and community was included to the modern criminological thinking only at the end of the 1980 via works of sociologically oriented criminologists - Howard Zehr, Tony F. Marshall, Mark Umbreit or John Braithwaite, it is not a pure opinion product, but rather a modified return to the common law of the indigenous peoples of North America, Australia, New Zeeland and some parts of Africa.

There is no definition of the concept of the restorative justice on a universal level ${ }^{12}$, it is possible to define it through the essential and generally acceptable principles:

- Crime shall not be considered either to be a violation of social order or an overrun of abstract legal and moral rules; it shall be understood mainly as a damage (harm) that was caused to the victim and as a threat of the safety of society;

- Damage caused to the victim must be understand in a broader sense - it is a material, physical, psychical harm, loss of social status, disruption of social ties, personal and family life;

- Reaction to the crime shall contribute to a decrease/removal of this damage and threat;

- The main purpose of social reaction to the committed crime shall not be the punishment of the offender or his re-education or deterrence, but creating such conditions that the consequences of crime could be removed;

- Tendencies towards tightening penal repression (imposing stricter penalties) is counterproductive, especially in case of juvenile offenders;

- The offender shall participate actively in compensation for damage for the harm suffered (in removal the detrimental consequences of the crime) and he shall be preserved all rights as those of other citizens;

- If the offender is not willing to participate voluntarily in this removal of consequences of the crime, he is forced by the court;

- State bodies shall engage in the restorative justice system only when the pure negotiation procedure between the offender and the victim does not lead to any aim or the committed crime is of such kind (seriousness) that the classical criminal trial is inevitable;

12 On the regional level of the Council of Europe, the Recommendation CM/Rec(2018)8 of the Committee of Ministers to member States concerning restorative justice in criminal matters was adopted in 2018. Point 3 defines restorative justice as "any process which enables those harmed by crime, and those responsible for that harm, if they freely consent, to participate actively in the resolution of matters arising from the offence, through the help of a trained and impartial third party.". 
- Victim of the crime cannot be forced to any negotiation with the offender about the way and extent of the compensation for damage (Karabec, 2003: 10).

Recommendation CM/Rec(2018)8 of the Committee of Ministers to member States concerning restorative justice in criminal matters defines key principles of the restorative justice in criminal matters so that the core principles of restorative justice are that the parties should be enabled to participate actively in the resolution of crime (the principle of stakeholder participation), and that these responses should be primarily oriented towards addressing and repairing the harm which crime causes to individuals, relationships and wider society (the principle of repairing harm). Other key restorative justice principles include: voluntariness; deliberative, respectful dialogue; equal concern for the needs and interests of those involved; procedural fairness; collective, consensus-based agreement; a focus on reparation, reintegration and achieving mutual understanding; and avoiding domination. These principles may be used as a framework with which to underpin broader reforms to criminal justice (Recommendation $\mathrm{CM} / \operatorname{Rec}(2018) 8$. art. 13).

\section{Principles of Restorative Justice}

\section{a) Support Victim and Healing is a Priority.}

When Liebmann (2007) is talking about restorative justice, he often ask whether anyone has been a victim of crime - often half or all the audience put their hands up - then ask what they would have wanted after the crime. Almost all of them mention things they needed (mainly their property back etc.) rather than punishment for the offender (p. 26).

\section{b) Offenders take Responsibility for what they have done.}

Offenders are used to take punishment but this is different like to taking responsibility for what they have done. Offenders suppose „I've done my time, I've paid my debt to society“, while in reality they had cost the state a lot of money and had not given a thought to those they had harmed. To take responsibility means to say „Yes, I did it and I take responsibility for the harm I caused“. From this statement starting point restorative justice. 


\section{c) Achieve Dialogue Leading to Understanding.}

A lot of victims have questions: Why me? Why my house? Is it likely to happen again? Etc. Only one person knows and can answer these questions. Some of offenders do not understand how they have harmed their victims, "What is the problem? They can get it back on insurance, can't they?". The offenders realize when they hear from victim what they did.

\section{d) There is an Attempt to put Right the Harm Done.}

Further step should be logically to take responsibility for doing harm is to try to put things right, as far as possible. Sometimes an apology is enough but mostly not. Sometimes the community has been harmed and these needs putting right, an example might be removing graffiti on an elderly persons' home.

\section{e) Preventing Recidivism of the Offender.}

Once, when offenders have realized the harm they have done, they usually don't like the idea of repeating their behavior. Many offenders have problems that lead to offending, such as homelessness, drugs or alcohol - they may need considerable help to avoid future offending and build a different kind of life. Restorative justice need to go hand in hand with the resources to achieve this. This is long run, most victims are interested in offenders avoiding future offending, thereby preventing the creation of more victims.

\section{f) Reintegration of Victim and Offender.}

As Liebman (2007) notes, the offenders need to be reintegrated into the community, especially after a prison sentence. They need accommodation, jobs and relationship to become positive members of the community. On the other hand, victims need reintegrating into the community too. They often feel alienated and cut off as a result of crime (p. 26). 


\section{Features of Restorative Justice}

There are three basic pillars of restorative justice: harm and need, obligation, engagement.

\section{a) The Restorative Justice Focuses on Harm.}

The term "restorative justice" means in the first place the harm done by crime, specifically to people and the society. Our legal system focuses on the law (rules), which sees the state as the main victim. The goal of restorative justice is to provide experience with rehabilitation to all involved parties.

\section{b) Wrongs and Harms Resulting in Obligations.}

The restorative justice emphasizes that the offender should be accountable for his acts. The offender assuming responsibility is the basic step for the restorative justice to operate. If the way of punishing the offender is to put him into an institution to serve a term of imprisonment and thus restricting his personal freedom, then the restorative justice cannot be applied. The offender has to realise that he caused harm and, especially, he has to assume responsibility for his acts. The offender has to understand the consequences of his acts. He also has the obligation to restore the damage caused to the highest extent possible.

The first obligation is on the offender's side but let's not forget also the obligation of the society as such that lies in the reintegration of the offender and postpenitentiary care.

\section{c) Restorative Justice Supports Participation or Engagement.}

The principle of engaging the offender lies in influencing the parties directly affected by the act - the victim, the offender and members of society - they have an important role in the criminal procedure. These involved parties must be provided with information about each other and at the same time they need to know what the prosecuting authorities need from them.

In some cases it might concern dialogues between parties that commonly take place between the offender and the victim at victim offender conferences. Opinions are shared and consensus is sought during such 
conferences. In other cases, indirect parties, such as surrogates, might be involved.

The engagement principle means involving an enlarged circle of parties as compared to the traditional justice process.

\section{The Restorative Justices Requires, at Minimum:}

- compensating the victims and addressing their needs,

- preparation of offenders and holding them accountable to restore the damage and

- subsequently the involvement of victims and offenders and the society into this process (Zehr, 2002: 22).

\section{Features of Restorative Justice:}

1. To focus on consequences of the crime more than on the fact that the law was breached.

2. To show the same concern and resolution towards the victim and the offender that involves the participation of both in the justice process.

3. To work on the compensation of victims, to strengthen them in addressing needs as they perceive them.

4. To support and encourage offenders in the understanding and acceptance of obligations, to make them fulfil their obligations.

5. To recognise obligations that might be more difficult for offender and should not be seen as something harmful and that should be, at the same time, attainable.

6. To provide opportunity for dialogue, direct or indirect, between the victim and the offender.

7. To find meaningful ways how to involve the society in the process.

8. To support cooperation and reintegration of victims and offender rather than to apply coercion and isolation.

9. To pay attention to thoughtless consequences of one's own acts.

10. To respect all parties - the victim, the offender and the society (Beck, Kropf, \& Leonard, 2011: 43).

\section{Restorative justice methods in prison system}

In criminal justice, restorative justice can be used relatively broadly in any phase of the criminal proceedings: from the pre-trial proceedings, within which it is possible to use a diversion from hearing of minor offences in the court (in conditions of the Slovak Republic for example condi- 
tional suspension of criminal proceedings ${ }^{13}$; conciliation $^{14}$; plea bargain ${ }^{15}$ ), through decision of the court through the court hearing and imposition of some of the alternative penalties to the enforcement proceedings. ${ }^{16}$

The Slovak Republic belongs to countries that reflected some principles of the restorative justice concept in its legislation and enforces them gradually (though not ideally) in the application practice. Of specific importance were those legal norms that

- Regulated the status of the victim, ${ }^{17}$

- introduced new - less formal addressing of criminal cases, extended the range of penalties by selected alternative sanctions ${ }^{18}$ and

- established bodies for ensuring their enforcement or introduced selected technical conditions for their enforcement. ${ }^{19}$

The restorative justice concept has its limits for example in case of multiple recidivists and horrendous crimes. Despite it, the restorative principles can modify also conditions of prison sentence execution. In this context, we speak about "the restorative prison system" as about the system that should eliminate the adverse effects of prisonisation. As it is known, the decisive precondition for the correctional (resocialisation) effect of the prison sentence execution is the acknowledgment of one's on guilt and fairness of the penalty on the part of the prisoner. Good practices of the restorative justice could facilitate this, for example contact between the prisoner and the victim (in extreme cases for example with survivors) that would strengthen the subjective sense of guilt and motivate the offender to retrieval of consequences of his act, compensation for damage and thus to re-education (Karabec, 2003: 12).

Penetration of the restorative justice principles into the environment of instructions, guidelines, regime activities and hierarchical arrangement

13 Penal Code, para 216 and 217.

14 Penal Code, 220 to 227.

15 Penal Code, 232 and 233.

16 Note - in our opinion, the very imposition of an alternative penalty is not possible to consider to be a fulfilment of the restorative justice concept. Alternative penalties are elements of restorative justice only if their execution is connected with activities and participation of the prisoner in the program focused on a real takeover of responsibility and compensation for damage of the victim at all levels (material, emotional and social). Without this dimension, the alternative penalty is only an expression of a revenge for commission of a crime.

17 Act No 274/2017 Coll. on Victims of Crimes as amended of 12 October 2017 retrieved from https:// www.slov-lex.sk/pravne-predpisy/SK/ZZ/2017/274/20200101.

18 Penal Code and Code of Criminal Procedure

19 Act No 550/2003 Coll. on Probation and Mediation Officers as amended of 28 October 2003 retrived from https://www.slov-lex.sk/pravne-predpisy/SK/ZZ/2003/550/20190801; Act No 78/2015 Coll. on Review of Enforcement of Some decision by Technical Means as amended of 19 March 2015 retrived from https://www.slov-lex.sk/pravne-predpisy/SK/ZZ/2015/78/20190101. 
can deepen the multidisciplinary status of pre-trial detention and prison sentence execution - not only from the penological, sociological and psychological viewpoint, but also from the viewpoint of its legal inclusion. Thus, pre-trial detention and prison sentence execution are not purely a penal-legal domain, but it is a "hybrid" tool that combines elements of constitutional law, criminal law, administrative law, social security law, civil or family law.

Despite the Act No 221/2006 Coll. on Pre-trial Detention as amended and Act No 475/2005 Coll. on Prison Sentence Execution as amended do not expressly regulate the concept "restorative program, restorative activity and the like", the legislation of treatment of inmates takes their realisation indirectly into account (rather unconsciously as purposively). The aim of treatment of prisoners is inter alia to facilitate and develop the sense of responsibility, respect for the law and social norms, positive personal qualities, respect for other people, self-respect and positive relation to family. For meeting the aim of the treatment purpose, a treatment program is worked out for every prisoner that includes a complex of activities focused on development of the personality of the prisoner, his adequate behaviour and value orientation. Thus, the first frame underpinnings of the restorative ideas can be seen in the treatment program.

The situation varies in some other countries. Restorative programs focused on enhancement of the responsibility towards victims are realized deliberately. Program called "Focus on Victims" realized in 2001 in Belgium was one of the first of these programs in Europe (Diblíková, 2003: 57). Mainly activities realized in the Czech Republic constitute an inspiring foreign practice taking into account the historical, cultural and legal proximity. Czech Prison Service gains the necessary knowledge by means of two projects:

1. Project called "A Fragile Chance II." - Czech probation and mediation service and prison service pilot-verify inter alia two programs within this project (Probační a mediační služba, n.d., Krehká šanca II section):

- Victim Impact Training - the aim of the activity is the pilot-realization of a special program of treatment of prisoners in 7 prisons and

- Restorative Practice Development - the aim of the activity is to introduce a model of regular communication and cooperation between the local community and prison focused on support of preparation of incarcerated offenders for their return into society 
2. Project called "Building bridges" realized by the Prison Fellowship International pilot-implemented in two Czech prisons as a moderated meeting between victims and offenders (Mezinárodní vězenské spoločenství, n.d., Building bridges section).

\section{Conclusion}

Prisons and prison system cannot be examined separately but always in relation to its addressees. Though primarily the prison system is a part of the criminal system, it is not merely a legal category, but similarly as a crime, also its consequence has to relate the existence, infringement and settlement of the basic relation of the individual, community and society. In this relation, there are objective rules and patterns that the prison environment has to respect as a part of the continuous process of reaction to crimes, thus from apprehension, through sentencing, sentence completion also after the prison sentence execution.

Experience gained in the foreign programs create preconditions for development of restorative principles in the following areas:

- Restorative programs ensuring settlement of the relation between the offender and the victim;

- Restorative programs enhancing the return of prisoners into family environment and community;

- Restorative programs as a dynamic security element and a toll for conflict solution inside prisons.

\section{REFERENCES}

Barnett, R. (2003). Restitution: a new paradigm of criminal justice. In G. Johnstone, A restorative justice reader (pp. 46-55). Portland: Willan Publishing.

Beck, E., Kropf, N. P., \& Leonard, P. B. (2011). Social work and restorative justice: Skills for dialogue peacemaking and reconciliation. New York, NY: Oxford University Press.

Dianiška, G., Strémy, T. (2009). Introduction to Criminology. Plzeň: Aleš Čeněk.

Diblíková, S. (2003). Restorativní justice a vězeňství. In Z. Karabec, Restorativní justice - Sborník př́spěvků a dokumentů (pp. 55-69). Praha: Institut pro Kriminologii a sociální prevenci.

Fábry, A. (2012). Väzenie. História a súčasnosț. Plzeň: Aleš Čenek. 
Karabec, Z. (2003). Koncept restorativní justice. In Z. Karabec, Restorativní justice - Sborník příspěvků a dokumentů (pp. 5-20). Praha: Institut pro Kriminologii a sociální prevenci.

Liebmann, M. (2007). Restorative Justice: How It Works. London: Jessica Kingsley Publishers.

Mccold, P. (2006) The recent history of restorative justice - Mediation, circles, and conferencing. In D. Sullivan \& L. Tifft (ed.), Handbook of Restorative Justice. Abingdon (pp. 35-41). Oxon: Routledge.

Paníček, F. (1970). Výkon trestu odňatia slobody v minulosti a dnes. Bratislava: Publishing house Obzor, n. p.

Zehr, H. (2002). The little book of Restorative Justice. Intercourse, PA: Good Books.

\section{Law references:}

Act No 59/1965 Coll. on Prison Sentence Execution of 17 June 1965 retrieved from https://www.slov-lex.sk/pravne-predpisy/SK/ZZ/1965/59/20030901.

Act No 550/2003 Coll. on Probation and Mediation Officers as amended of 28 October 2003 retrived from https:/www.slov-lex.sk/pravne-predpisy/SK/ ZZ/2003/550/20190801.

Act No 475/2005 Coll. on Prison Sentence Execution of 22 September 2005 retrieved from https://www.slov-lex.sk/pravne-predpisy/SK/ZZ/2005/475/20190701.

Act No 221/2006 Coll. on Pre-Trial Detention of 15 March 2006 retrieved from https:// www.slov-lex.sk/pravne-predpisy/SK/ZZ/2006/221/20160701.

Act No 78/2015 Coll. on Review of Enforcement of Some decision by Technical Means as amended of 19 March 2015 retrived from https://www.slov-lex.sk/pravne-predpisy/SK/ZZ/2015/78/20190101.

Act No 274/2017 Coll. on Victims of Crimes as amended of 12 October 2017 retrieved from https://www.slov-lex.sk/pravne-predpisy/SK/ZZ/2017/274/20200101.

Decree of the Ministry of Justice of the Slovak Republic No 437/2006 Coll. that issues Rules of Pre-Trial Detention of 26 June 2006 retrieved from https://www.slov-lex. sk/pravne-predpisy/SK/ZZ/2006/437/20150701.

Decree of the Ministry of Justice of the Slovak Republic No 368/2008 Coll. that issues Rules of Prison Sentence Execution of 3 September 2008 retrieved from https:// www.slov-lex.sk/pravne-predpisy/SK/ZZ/2008/368/20160101.

Recommendation No. R (87) 3 on the European Prison Rules of 12 February 1987 retrieved from https://rm.coe.int/16804f856c.

Report of the Tenth United Nations Congress on the Prevention of Crime and the Treatment of Offenders, 10-17 April 2000, A/CONF.187/15 retrieved from https:// digitallibrary.un.org/record/432663? $\ln =\mathrm{en}$.

The UN Standard Minimum Rules for the Treatment of Prisoners of 31 July 1957 retrieved from https://www.unodc.org/pdf/criminal_justice/UN_Standard_Minimum_Rules_for_the_Treatment_of_Prisoners.pdf. 


\title{
Websites:
}

Probační a mediační služba (n.d.). Krehká šanca II. Retrived 17 August 2020 from https://www.pmscr.cz/krehka-sance-ii/.

Mezinárodní vězenské spoločenství (n.d.). Building bridges. Retrived 17 August 2020 from http://mvs.cz/building-bridges/.

\section{УТИЦАЈ РЕСТОРАТИВНЕ ПРАВДЕ НА ЗАТВОРСКИ СИСТЕМ}

\author{
Томаш Стреми \\ Универзитет Коменског у Братислави, Правни факултет \\ Јозеф Григер \\ Генерални директорат формације затворских \\ и судских стражара (Словачка)
}

\section{Сажетак}

Историја затвора подразумева примену различитих концепција и начина организовања извршења казне затвора. Реформатори су покушали да обликују затворски режим у складу са својим идејама, али стварност затворског система показала је суштинска ограничења њихових залагања (на пример, високи трошкови за изградњу затвора; ниво криминалитета, минимална заштита будућих жртава итд.). У другој половини 20. века почиње потрага за новим начинима решавања проблема криминалитета и спровођења казнене политике. Идеја ресторативног затвора тренутно постоји само као концепт. Овај приступ је заснован на могућности да се затвореник сусретне са својим стварним жртвама у оквиру обнављајућег дијалога. Ресторативни програми такође олакшавају повратак затвореника у породично окружење и заједницу и унапређују динамичку сигурност затвореника у затвору.

Кључне речи: затвор, извршење казне затвора, ресторативна правда, ресторативни програми. 